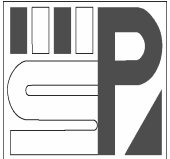

Science Press
Journal of Arid Land

2012, 4(4): 420-430

doi: 10.3724/SP.J.1227.2012.00420

jal.xjegi.com; www.chinasciencejournal.com

\title{
Changes in soil carbon stocks and related soil proper- ties along a 50-year grassland-to-cropland conversion chronosequence in an agro-pastoral ecotone of Inner Mongolia, China
}

\author{
Yan $\mathrm{JIAO}^{1,2 *}$, Zhu XU ${ }^{2}$, JiaoHong ZHAO ${ }^{1}$, WenZhu YANG ${ }^{1}$ \\ ${ }^{1}$ College of Chemistry and Environmental Sciences, Inner Mongolia Normal University, Hohhot 010018, China; \\ ${ }^{2}$ Grassland Research Institute of Chinese Academy of Agriculture Science, Hohhot 010018, China
}

\begin{abstract}
Land use change significantly influences soil properties. There is little information available on the long-term effects of post-reclamation from grassland to cropland on soil properties. We compared soil carbon (C) and nitrogen $(\mathrm{N})$ storage and related soil properties in a 50-year cultivation chronosequence of grassland in the agro-pastoral ecotone of Inner Mongolia. Field surveys on land use changes during the period of 1955-2002 were conducted to build a chronosequence of cropland of different ages since the conversion from grassland. The results showed that soil $\mathrm{C}$ and $\mathrm{N}$ storage, soil texture, and soil nutrient contents varied with land use types and cropland ages $(P<0.01)$. In the $0-30 \mathrm{~cm}$ soil layer, the soil organic carbon (SOC) density was significantly lower in the croplands $\left(3.28 \mathrm{~kg} \mathrm{C} / \mathrm{m}^{2}\right.$ for $\mathrm{C} 50$ soil) than in the grasslands $\left(6.32 \mathrm{~kg} \mathrm{C} / \mathrm{m}^{2}\right)$. After $5,10,15,20,35$, and 50 years of crop planting (years since the onset of cultivation), the SOC losses were $17 \%, 12 \%, 19 \%, 47 \%, 46 \%$, and $48 \%$, respectively, compared with the grasslands. The soil total nitrogen (TN) density of the grasslands was $65 \mathrm{~g} \mathrm{~N} / \mathrm{m}^{2}$, and TN density of the cropland soil was $35 \mathrm{~g} \mathrm{~N} / \mathrm{m}^{2}$ after 50 years of crop planting. Both the SOC and TN densities could be quantitatively determined by a negative exponential function of cropland age $\left(P<0.0001, R^{2}=0.8528 ; P<0.0001\right.$, $R^{2}=0.9637$ ). The dissolved organic carbon (DOC) content, soil available potassium (AK) content, clay content, and $\mathrm{pH}$ value were decreased; and the soil bulk density and sand content were increased since the conversion of grassland into cropland during the 50-year period. Our results show soil nutrients were higher in grassland than in cropland. The conversion of grasslands to croplands induced a loss of soil $\mathrm{C}$ storage and changes of related soil properties. The reclamation time of cultivated soil (cropland age) had significant effects on soil properties in the study area.
\end{abstract}

Keywords: land use type; cropland age; grassland; soil physical-chemical properties; agro-pastoral ecotone

In recent years, numerous studies have focused on soil organic carbon (SOC) changes in various ecosystems (Powlson, 2005). Land use change obviously affects soil C (Houghton, 1999; Zhang, 2010) and N (Potter et al., 1996) cycles. Many studies have reported the effects of land use change from cropland or grassland to forest and vice versa (Post and Kwon, 2000; Guo and Gifford, 2002). There is generally more SOC in grassland soil than in cropland soil (Cole et al., 1993). In China, 8, 16, and 41 years after alpine grassland soils were converted to arable land, the organic matter contents in the soils decreased by $25 \%, 39 \%$, and $55 \%$, respectively (Wu and Tiessen, 2002). Celik (2005) reported that the soil organic matter of cropland soils decreased by $48 \%$ for the $0-10 \mathrm{~cm}$ soil depth and $50 \%$ for the 10-20 cm soil depth compared with pasture soils over 12 years. Previous investigations seldom quantified the effects of reclamation age (years since

Received 2012-02-21; accepted 2012-06-11

*Corresponding author: Yan JIAO (E-mail: jiaoyan@imnu.edu.cn) 
the onset of cultivation) on soil carbon and nitrogen storage. Because it takes decades to centuries before the total $\mathrm{C}$ in soils equilibrates, it has been suggested that more sensitive soil $\mathrm{C}$ fractions should be investigated, such as dissolved organic carbon (DOC; Cambardella and Elliot, 1992). These C components have turnover time from years to decades. Therefore, DOC is easier to detect after land use change. In general, DOC concentrations vary in the following order: forest soils $>$ grassland soils $>$ arable soils. This order is mostly due to different types of plant cover (Delprat et al., 1997; Haynes, 2000).

Nitrogen and phosphorus are key factors that influence the primary production of ecosystems (Mooney et al., 1987; Han et al., 1999). Land use and related management practices affect soil properties, such as SOC content, and are therefore likely to influence soil available potassium (AK) content and soil available phosphorus (AP) content.

In contrast to the vast literature on agricultural soils, few studies have compared the effects of the long-term conversion from grassland to arable land on soil physical properties (Pedersen et al., 1980; Skousen et al., 1998; Shukla et al., 2004a). Soil physical properties change significantly with land degradation in the form of bulk density (Tisdall and Oades, 1982; Elliott, 1986). Bulk density is the most discriminating factor in soil properties in relation to land use and management (Shukla et al., 2004b). Celik (2005) showed that cultivated soils have higher bulk density than adjacent soils under forests and pastures in the southern Mediterranean highlands of Turkey. Soil clay content is also a significant soil property (Mapa and Kumaragamage, 1996). He et al. (2005) and Li et al. (2006) proved that the sand $(1-0.05 \mathrm{~mm})$ content of cropland soils is higher than that of grassland soils. The return of plant residue to grassland soil results in soil organic humus enrichment and soil organic matter turnover (Angers and Caron, 1998).

Land use conversion from grassland to cropland and vice versa has occurred in the arid and semi-arid lands (ASAL) of Asia during the $20^{\text {th }}$ century. The carbon and nitrogen cycles in this region show high temporal and spatial variability, with some areas acting as carbon sources and others as carbon sinks. Understanding the mechanisms that regulate carbon fluxes in and out of the ASAL ecosystems would contribute to our knowledge of the complex carbon cycles of terrestrial ecosystems.

The agro-pastoral ecotone of Inner Mongolia lies within the arid and semi-arid regions of Asia. The agro-pastoral ecotone is distributed from northeast to southwest in China, covering 30\% of the Chinese land territory. The agro-pastoral ecotone is a transition of land-use practices (livestock-grazing and farming) in places where grassland and cropland are interspersed. The economic reform of China has led to the large-scale conversion of grassland to cropland at the Inner Mongolian Plateau in North China. In the agro-pastoral ecotone, cropland areas were increased by $43,700 \mathrm{hm}^{2}$ due to the reclamation of grassland into cropland (Liu, 2002). In these areas, precipitation is less; land-use types are often diverse and the changes are more frequent. Overgrazing and land use changes that reduce the areas of forests and grasslands (Liu and Tong, 2003; Zhan et al., 2004) along with an increase in agricultural activity have intensified pressures on the regional grasslands, causing severe land degradation (Liu and Tong, 2003; Zhan et al., 2004). The agro-pastoral ecotone is ecologically fragile, and the shift from grassland to cropland is attracting increasing concerns from scholars (Zou, 2003).

In this paper, we investigated and compared soil C, $\mathrm{N}$ storage and related physical-chemical properties in a 50-year cultivation chronosequence of cropland in the agro-pastoral ecotone of Inner Mongolia. Grasslands that have never been ploughed were compared with croplands that were converted from grasslands in 1956, 1971, 1986, 1991, 1997, and 2002.

The aims of this research were to explain the variation in soil properties affected by land use changes and provide information for optimizing land use practices and improving soil ecological functions.

\section{Materials and methods}

\subsection{Study area}

The study area, with an altitude of approximately 1,400 m, is located in Taipusi county of Inner Mongolia, which lies within the typical agro-pastoral areas of China. It is in the south of the steppe of Xinlin River Basin, which constitutes an important component of 
the Eurasian temperate grassland (Zhang et al., 1997; Wang and Wang, 2007). The grassland in this study area is native (Chen and Wang, 2000).

The study area covers $2,667 \mathrm{hm}^{2}$, of which open forest occupies $667 \mathrm{hm}^{2}$, grassland $1,333.33 \mathrm{hm}^{2}$, and cropland $667 \mathrm{hm}^{2}$. This region belongs to the semi-arid temperate climatic zone (Taipusi Government, 1989). The annual mean temperature is approximately $1.6^{\circ} \mathrm{C}$. The lowest monthly mean temperature is $-17.6^{\circ} \mathrm{C}$ in January, and the highest is $17.8^{\circ} \mathrm{C}$ in July. The annual mean precipitation is 400 $\mathrm{mm}$. The wind speed is $6 \mathrm{~m} / \mathrm{s}$ (Yang et al., 2005). The growing period of plants is from late April to early October.

Grasslands are the most important land use type in the Xilin River Basin. The dominant grass species include Leymus chinensis, Stipa grandis, Stipa krylovii, Agropyron cristatum and Artemisia frigida. The soil is sandy chestnut (i.e. Calcic Kastanozems, which is equivalent to Calcic-orthic Aridisol in the US soil taxonomy classification system).

\subsection{Soil sampling and analysis}

Field sampling was done in October 2007. The soils were sampled randomly from 7 sites within adjacent land use types, including flat areas of grassland and cropland (Table 1). All these sites were approximately more than $10 \mathrm{hm}^{2}$ and presented similar slope and soil type. There were 10 sampling sites with 3 replicates for each site. These 7 sites were sampled in the 3 layers of $0-10,10-20$ and $20-30 \mathrm{~cm}$ using a stainless steel corer (4 $\mathrm{cm}$ in diameter). The mean sampling interval was $50 \mathrm{~m}$ for both grassland and cropland, with 210 soil sampling sites and a total of 630 samples. The croplands originated from the reclamation of grasslands from 1955 to 2002.
Croplands reclaimed for 5 (C5), 10 (C10), 15 (C15), 20 (C20), 35 (C35), and 50 (C50) years were used to produce potato, wheat, and barley in $2007 . \mathrm{N}, \mathrm{P}, \mathrm{K}$ compound fertilizers were applied before planting (Table 2). The crop rotation patterns were dominated by potato-wheat-barley for the C5, C10, C15, C20, C35 and C50 soils from 1970 to 2007.

The crops were harvested in September, and the soil was then left bare from September to the following June. The soil was plowed before planting every year. The plowing depth was $30-35 \mathrm{~cm}$.

The samples were air-dried and sieved through a 2-mm mesh for chemical analysis. Soil samples for soil bulk density analysis were taken using a steel cylinder which is $4 \mathrm{~cm}$ in diameter and $5 \mathrm{~cm}$ in height. The bulk density, SOC, total nitrogen (TN), soil texture, soil available phosphorous, and soil available potassium were analyzed according to the method of Liu (1996).

Table 1 Site characteristics of agro-pastoral ecotone in the Taipusi county of Inner Mongolia

\begin{tabular}{cccl}
\hline Site & Latitude & Longitude & Land use history \\
\hline $\mathrm{G}$ & $41^{\circ} 49^{\prime} 52^{\prime \prime} \mathrm{N}$ & $115^{\circ} 13^{\prime} 26^{\prime \prime} \mathrm{E}$ & Natural grassland \\
$\mathrm{C} 5$ & $41^{\circ} 50^{\prime} 29^{\prime \prime} \mathrm{N}$ & $115^{\circ} 13^{\prime} 19^{\prime \prime} \mathrm{E}$ & Cropland reclaimed for 5 years \\
$\mathrm{C} 10$ & $41^{\circ} 50^{\prime} 49^{\prime \prime} \mathrm{N}$ & $115^{\circ} 13^{\prime} 43^{\prime \prime} \mathrm{E}$ & Cropland reclaimed for 10 years \\
$\mathrm{C} 15$ & $41^{\circ} 50^{\prime} 54^{\prime \prime} \mathrm{N}$ & $115^{\circ} 14^{\prime} 02^{\prime \prime} \mathrm{E}$ Cropland reclaimed for 15 years \\
$\mathrm{C} 20$ & $41^{\circ} 50^{\prime} 53^{\prime \prime} \mathrm{N}$ & $115^{\circ} 14^{\prime} 05^{\prime \prime} \mathrm{E}$ Cropland reclaimed for 20 years \\
$\mathrm{C} 35$ & $41^{\circ} 48^{\prime} 28^{\prime \prime} \mathrm{N}$ & $115^{\circ} 19^{\prime} 13^{\prime \prime} \mathrm{E}$ Cropland reclaimed for 35 years \\
$\mathrm{C} 50$ & $41^{\circ} 50^{\prime} 53^{\prime \prime} \mathrm{N}$ & $115^{\circ} 13^{\prime} 23^{\prime \prime} \mathrm{E}$ Cropland reclaimed for 50 years
\end{tabular}

Note: G means natural grassland; C5, C10, C15, C20, C35, and C50 mean cropland reclaimed for $5,10,15,20,35$, and 50 years, respectively. The same below.

Table 2 Information for the investigated land and planting history of the sample sites

\begin{tabular}{cllc}
\hline Treatment $^{\mathrm{a}}$ & Plant name & Planting history & Mean age $^{\mathrm{b}}$ \\
\hline $\mathrm{G}$ & Leymus chinensis, Stipa capillata & Undisturbed natural grassland & 5 \\
$\mathrm{C} 5$ & Potato & Potato was planted in 2006 and 2007 & 10 \\
$\mathrm{C} 10$ & Potato, oat & Two years of rotation of potato and oat. Potato was planted in 2007 and oat in 2006 \\
C15 & Wheat & Wheat was planted in 2006 and 2007 & $15 \pm 2$ \\
C20 & Wheat & Wheat was planted in 2006 and 2007 & $20 \pm 2$ \\
C35 & Wheat & Wheat was planted in 2006 and 2007 & $35 \pm 3$ \\
C50 & Potato & Potato was planted in 2006 and 2007 & $50 \pm 5$ \\
\hline
\end{tabular}

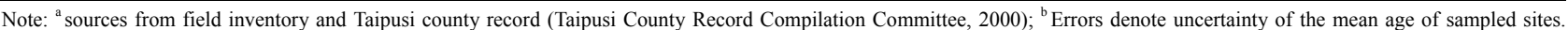
Once cropland was plowed, N, P, K compound fertilizer $\left(450 \mathrm{~kg} / \mathrm{km}^{2}\right)$ was incorporated in soil before annual planting. 
Samples of $0.5 \mathrm{~g}$ soil were digested with $5 \mathrm{ml}$ of $1 \mathrm{~N} \mathrm{~K}_{2} \mathrm{Cr}_{2} \mathrm{O}_{7}$ and $10 \mathrm{ml}$ of concentrated $\mathrm{H}_{2} \mathrm{SO}_{4}$ at $150^{\circ} \mathrm{C}$ for $30 \mathrm{~min}$, followed by titration of the digests with standardized $\mathrm{FeSO}_{4}$ to measure SOC. The TN was measured using the Kjeldahl digestion procedure (Horneck and Miller, 1998). Dissolved organic carbon in the soil samples was measured using a Total Organic Carbon Analyzer (MODEL TOC-5000A, SHIMADZU, Kyoto, Japan). Concentrations of total C (TC) and inorganic C (IC) in the prepared soil supernatant liquid were determined by the combustion/nondispersive infrared gas analysis method (de Castro et al., 1999). The DOC was then determined by subtracting the IC from the TC concentration.

\subsection{Calculation of SOC density and statistical analysis}

The SOC density and TN density were calculated as follows (Zhou et al., 2007):

$$
\begin{gathered}
\text { SOC density }=\sum_{i=1}^{n} D_{i} \times B_{i} \times O_{i}, \\
\text { TN density }=\sum_{i=1}^{n} D_{i} \times B_{i} \times N_{i} .
\end{gathered}
$$

Where, $n$ is the number of soil horizons, $\mathrm{D}_{i}$ the depth interval $(\mathrm{cm})$ of horizon $i$ from the topsoil downward, $\mathrm{B}_{i}$ the bulk density (BD) $\left(\mathrm{g} / \mathrm{cm}^{3}\right)$ in horizon $i, \mathrm{O}_{i}$ the mean SOC content (\%) in horizon $i$, and $\mathrm{N}_{i}$ the mean TN content (\%) in horizon $i$.

A statistical analysis was performed using the SYSTAT 10.0 program. An analysis of variance (ANOVA) was used to determine the significant differences in the mean BD $\left(\mathrm{g} / \mathrm{cm}^{3}\right)$, SOC (\%), SOC density $\left(\mathrm{kg} \mathrm{C} / \mathrm{m}^{2}\right), \mathrm{DOC}(\mathrm{mg} / \mathrm{L}), \mathrm{TN}\left(\mathrm{g} / \mathrm{m}^{2}\right), \mathrm{AP}, \mathrm{AK}$ and soil clay content among the depth intervals and between the land uses in each site at $P<0.05$. The analyses of land use were performed using the SYSTAT 10.0 program with land use as a fixed variable. Corre- lation and regression analyses were performed using the SYSTAT 10.0 program.

\section{Results and discussion}

\subsection{Distribution of bulk density and soil texture}

Soil bulk density was largely affected by land use and cropland age (Table 3). The bulk densities were $1.32-1.41, \quad 1.39-1.42, \quad 1.24-1.33, \quad 1.40-1.51$, $1.48-1.54$, and $1.35-1.40 \mathrm{~g} / \mathrm{cm}^{3}$ in the cropland soils $\mathrm{C} 5, \mathrm{C} 10, \mathrm{C} 15, \mathrm{C} 20, \mathrm{C} 35$, and $\mathrm{C} 50$ for the $0-30 \mathrm{~cm}$ horizons, respectively. The cropland soils did not differ in bulk density among the $0-10 \mathrm{~cm}, 10-20 \mathrm{~cm}$, and $20-30 \mathrm{~cm}$ layers $(F=0.1, P>0.1)$ (Table 3$)$. The cropland soil had a higher bulk density than the adjacent grassland in the $10-30 \mathrm{~cm}$ layers $(F=9.4, P<0.0001)$. The bulk density had an increasing trend with increased cropland age (the years since the onset of cultivation) $(F=6.8, P<0.0001)$. Franzluebbers et al. (2000) reported that the bulk density of grassland was significantly different from that of the conservation-tillage croplands in the upper $0.125 \mathrm{~m}$ of soil. Bauer and Black (1981) reported that the bulk density increased after the conversion of grasslands to croplands for a paired site investigation in North Dakota, USA. Some findings proved that cultivation readily induces soil loosening (Evrendilek et al., 2004; Celik, 2005). The bulk density in agricultural soils was significantly higher than that of grasslands, which could be a result of using heavy agricultural equipment for plowing, planting, harvesting, and applying fertilizers, herbicides, and pesticides. An important factor that influences bulk density is the SOC content. The lower SOC content in agricultural soils leads to a higher soil bulk density. Hajabbasi et al. (1997) showed that higher soil organic matter content could improve soil texture, resulting in a decrease of soil bulk density.

\begin{tabular}{|c|c|c|c|c|c|c|c|}
\hline \multirow{2}{*}{ Depth $(\mathrm{cm})$} & \multicolumn{7}{|c|}{ Soil bulk density $\left(\mathrm{g} / \mathrm{cm}^{3}\right)$} \\
\hline & G & $\mathrm{C} 5$ & $\mathrm{C} 10$ & $\mathrm{C} 15$ & $\mathrm{C} 20$ & $\mathrm{C} 35$ & $\mathrm{C} 50$ \\
\hline $0-10$ & $1.26 \pm 0.09$ & $1.32 \pm 0.17$ & $1.42 \pm 0.03$ & $1.33 \pm 0.05$ & $1.40 \pm 0.07$ & $1.54 \pm 0.09$ & $1.40 \pm 0.10$ \\
\hline $10-20$ & $1.25 \pm 0.02$ & $1.41 \pm 0.08$ & $1.39 \pm 0.18$ & $1.31 \pm 0.08$ & $1.44 \pm 0.12$ & $1.53 \pm 0.07$ & $1.35 \pm 0.06$ \\
\hline $20-30$ & $1.31 \pm 0.08$ & $1.33 \pm 0.07$ & $1.39 \pm 0.09$ & $1.24 \pm 0.09$ & $1.51 \pm 0.12$ & $1.48 \pm 0.08$ & $1.35 \pm 0.03$ \\
\hline $0-30$ & $1.27 \pm 0.05$ & $1.35 \pm 0.13$ & $1.40 \pm 0.11$ & $1.29 \pm 0.07$ & $1.45 \pm 0.10$ & $1.51 \pm 0.08$ & $1.36 \pm 0.08$ \\
\hline
\end{tabular}

Table 3 Effects of land use on soil bulk density and the vertical distribution of soil bulk density

Note: Mean \pm SD. 
Statistics show that the highest clay $(10.97 \%$ as an average for 3 depths) and the lowest sand contents ( $46.57 \%$ as an average for 3 depths) were found in the grassland (Table 4). In the $0-30 \mathrm{~cm}$ soil depths, the soil sand content $(F=0.5, P>0.1)$, clay content, $(F=0.613, P>0.5)$ and silt content $(F=0.1, P=0.933)$ did not change with the increase of soil depth. The soil sand content $(F=3.874, P<0.0001)$ increased with the increase of cropland age. Opposite to the trend for the sand content, the soil clay content $(F=3.9, P<0.0001)$, and silt content revealed a declining trend. The trend of higher soil sand content and lower clay content observed with increasing cropland age may be due to wind erosion. Cropland soil had a lower plant cover than grassland soil, because the land was bare from September to the following June. Being influenced by wind erosion, the soil fine particles were easily blew away, and the cropland was desertified after the reclamation of grassland. He et al. (2005) reported that cropland was more easily influenced by wind erosion than native grassland in agro-pastoral ecotones in Inner Mongolia. Li et al. (2006) proved that the sand content is higher in the cropland surface-layer and subsurface-layer soils than in grassland soils.

Table 4 Effects of land use on soil texture and the vertical distributions

\begin{tabular}{|c|c|c|c|c|}
\hline \multirow{2}{*}{ Treatment } & \multirow{2}{*}{ Depth $(\mathrm{cm})$} & \multicolumn{3}{|c|}{ Soil texture (\%) } \\
\hline & & Sand & Silt & Clay \\
\hline \multirow[t]{3}{*}{ G } & $0-10$ & 40.3 & 50.5 & 9.2 \\
\hline & $10-20$ & 50.4 & 38.0 & 11.3 \\
\hline & $20-30$ & 49.0 & 38.9 & 12.1 \\
\hline \multirow[t]{3}{*}{$\mathrm{C} 5$} & $0-10$ & 56.5 & 27.7 & 8.9 \\
\hline & $10-20$ & 50.3 & 35.2 & 8.4 \\
\hline & $20-30$ & 53.4 & 29.0 & 10.2 \\
\hline \multirow[t]{3}{*}{$\mathrm{C} 10$} & $0-10$ & 62.8 & 23.9 & 8.4 \\
\hline & $10-20$ & 62.5 & 24.5 & 7.9 \\
\hline & $20-30$ & 61.6 & 24.5 & 8.4 \\
\hline \multirow[t]{3}{*}{$\mathrm{C} 15$} & $0-10$ & 61.3 & 27.6 & 8.5 \\
\hline & $10-20$ & 61.4 & 25.5 & 9.6 \\
\hline & $20-30$ & 59.9 & 27.9 & 6.9 \\
\hline \multirow[t]{3}{*}{$\mathrm{C} 20$} & $0-10$ & 57.9 & 25.3 & 8.1 \\
\hline & $10-20$ & 61.2 & 21.9 & 9.9 \\
\hline & $20-30$ & 62.6 & 22.0 & 10.0 \\
\hline \multirow[t]{3}{*}{ C35 } & $0-10$ & 62.6 & 26.8 & 7.9 \\
\hline & $10-20$ & 65.1 & 25.2 & 7.9 \\
\hline & $20-30$ & 60.8 & 28.8 & 8.3 \\
\hline \multirow[t]{3}{*}{$\mathrm{C} 50$} & $0-10$ & 61.1 & 22.4 & 7.9 \\
\hline & $10-20$ & 61.3 & 20.3 & 7.9 \\
\hline & $20-30$ & 58.6 & 25.0 & 8.4 \\
\hline
\end{tabular}

In addition, the return of plant residues in the grassland soil and the lack of plowing caused the enrichment of soil organic humus and accelerated the formation of soil fine particles, which led to relatively higher clay content in grassland soil than in cropland soil. This development implies that the older the cropland age, the higher the soil sand content, which would lead to desertification in the study area.

\subsection{Changes in soil organic carbon density and to- tal nitrogen density}

The difference between the SOC contents of the grassland soils and the cropland soils was statistically significant $(F=64.1, P<0.0001)$. There were pronounced differences in the SOC contents among the cropland soils of different ages $(F=61.4, P<0.0001)$. We calculated the soil $\mathrm{C}$ and $\mathrm{N}$ density of up to a $30-\mathrm{cm}$ depth using measured $\mathrm{C}$ and $\mathrm{N}$ concentrations (Table 5) and bulk density. The results for the SOC densities at $0-10$ $\mathrm{cm}, 10-20 \mathrm{~cm}$ and $20-30 \mathrm{~cm}$ at the seven sites are shown in Fig. 1. For the $0-30 \mathrm{~cm}$ layers, the grassland soils had the highest value of $6.32 \mathrm{~kg} \mathrm{C} / \mathrm{m}^{2}$. The $\mathrm{SOC}$ density of $\mathrm{C} 5, \mathrm{C} 10, \mathrm{C} 15, \mathrm{C} 20, \mathrm{C} 35$ and $\mathrm{C} 50$ decreased by $17 \%, 12 \%, 19 \%, 47 \%, 46 \%$, and $48 \%$, respectively, compared with the grasslands in the $0-30 \mathrm{~cm}$ soil depths (Fig. 1). These results are consistent with a previous report by Wu et al. (2003), which estimated an SOC loss of $10 \%-40 \%$ in the cultivated soils relative to their non-cultivated counterparts in China. Guo and Gifford (2002) found that soil carbon stocks, at a global scale, declined by $59 \%$ after the conversion of pasture to cropland. There is generally more SOC in grassland soil than in cropland soil (Cole et al., 1993). In China, after alpine grassland soils were converted to arable land for 8,16 , and 41 years, the organic matter content in the soils decreased by $25 \%, 39 \%$, and $55 \%$, respectively ( $\mathrm{Wu}$ and Tiessen, 2002). Celik (2005) reported that the soil organic matter of cropland soils decreased by $48 \%$ for the $0-10 \mathrm{~cm}$ soil depth and 50\% for the 10-20 cm soil depth compared with pasture soils over 12 years. Lal (2002) also reported a carbon pool loss of $30 \%-50 \%$ in the midwestern USA due to land use changes from natural to agricultural ecosystems. Martin et al. (2010) tested that the amount of carbon loss from the soil was due only to changes in land use. 
Table 5 Comparisons of SOC, TN, AK, AP, and pH of cropland and grassland soils

\begin{tabular}{|c|c|c|c|c|c|c|}
\hline \multirow{2}{*}{ Treatment } & \multirow{2}{*}{ Depth $(\mathrm{cm})$} & \multicolumn{5}{|c|}{ Soil nutrient } \\
\hline & & SOC $(\%)$ & $\mathrm{TN}(\mathrm{g} / \mathrm{kg})$ & $\mathrm{AP}(\mathrm{mg} / \mathrm{kg})$ & $\mathrm{AK}(\mathrm{mg} / \mathrm{kg})$ & $\mathrm{pH}$ \\
\hline \multirow{3}{*}{ G } & $0-10$ & $2.46 \pm 0.01$ & $0.25 \pm 0.006$ & $5.30 \pm 0.57$ & $282 \pm 7.40$ & $8.0 \pm 0.05$ \\
\hline & $10-20$ & $2.22 \pm 0.05$ & $0.23 \pm 0.005$ & $3.09 \pm 0.28$ & $205 \pm 4.00$ & $8.1 \pm 0.02$ \\
\hline & $20-30$ & $1.54 \pm 0.03$ & $0.17 \pm 0.013$ & $2.97 \pm 0.37$ & $148 \pm 4.00$ & $8.7 \pm 0.09$ \\
\hline \multirow{3}{*}{$\mathrm{C} 5$} & $0-10$ & $1.58 \pm 0.05$ & $0.17 \pm 0.010$ & $7.15 \pm 0.35$ & $189 \pm 8.14$ & $7.6 \pm 0.08$ \\
\hline & $10-20$ & $1.53 \pm 0.12$ & $0.18 \pm 0.050$ & $7.20 \pm 0.28$ & $188 \pm 4.51$ & $7.6 \pm 0.12$ \\
\hline & $20-30$ & $1.31 \pm 0.07$ & $0.16 \pm 0.001$ & $4.15 \pm 0.35$ & $138 \pm 6.08$ & $7.6 \pm 0.07$ \\
\hline \multirow{3}{*}{$\mathrm{C} 10$} & $0-10$ & $1.30 \pm 0.02$ & $0.13 \pm 0.010$ & $9.80 \pm 0.14$ & $126 \pm 5.00$ & $7.6 \pm 0.01$ \\
\hline & $10-20$ & $1.31 \pm 0.03$ & $0.13 \pm 0.020$ & $5.30 \pm 0.18$ & $97 \pm 2.52$ & $7.6 \pm 0.05$ \\
\hline & $20-30$ & $1.34 \pm 0.01$ & $0.13 \pm 0.003$ & $3.23 \pm 0.13$ & $97 \pm 2.52$ & $7.6 \pm 0.05$ \\
\hline \multirow{3}{*}{$\mathrm{C} 15$} & $0-10$ & $1.41 \pm 0.02$ & $0.14 \pm 0.004$ & $5.15 \pm 0.64$ & $172 \pm 5.69$ & $7.7 \pm 0.02$ \\
\hline & $10-20$ & $1.41 \pm 0.02$ & $0.14 \pm 0.003$ & $3.11 \pm 0.28$ & $168 \pm 0.00$ & $7.7 \pm 0.08$ \\
\hline & $20-30$ & $1.38 \pm 0.09$ & $0.13 \pm 0.007$ & $3.17 \pm 0.58$ & $145 \pm 7.02$ & $7.8 \pm 0.11$ \\
\hline \multirow{3}{*}{$\mathrm{C} 20$} & $0-10$ & $1.05 \pm 0.08$ & $0.10 \pm 0.004$ & $10.15 \pm 1.64$ & $100 \pm 6.11$ & $7.1 \pm 0.10$ \\
\hline & $10-20$ & $1.03 \pm 0.09$ & $0.11 \pm 0.004$ & $5.41 \pm 1.13$ & $96 \pm 5.13$ & $7.4 \pm 0.04$ \\
\hline & $20-30$ & $0.74 \pm 0.02$ & $0.09 \pm 0.004$ & $2.15 \pm 0.04$ & $85 \pm 5.20$ & $7.6 \pm 0.02$ \\
\hline \multirow{3}{*}{ C35 } & $0-10$ & $0.79 \pm 0.07$ & $0.08 \pm 0.004$ & $9.10 \pm 1.56$ & $112 \pm 0.19$ & $6.9 \pm 0.06$ \\
\hline & $10-20$ & $0.72 \pm 0.04$ & $0.07 \pm 0.003$ & $4.19 \pm 0.50$ & $101 \pm 1.53$ & $6.9 \pm 0.02$ \\
\hline & $20-30$ & $0.77 \pm 0.10$ & $0.08 \pm 0.004$ & $3.16 \pm 0.66$ & $93 \pm 2.31$ & $7.3 \pm 0.02$ \\
\hline \multirow{3}{*}{$\mathrm{C} 50$} & $0-10$ & $0.79 \pm 0.13$ & $0.09 \pm 0.008$ & $30.35 \pm 0.21$ & $169 \pm 11.50$ & $7.6 \pm 0.03$ \\
\hline & $10-20$ & $0.93 \pm 0.11$ & $0.09 \pm 0.007$ & $18.30 \pm 1.41$ & $138 \pm 6.93$ & $7.6 \pm 0.11$ \\
\hline & $20-30$ & $0.81 \pm 0.04$ & $0.09 \pm 0.003$ & $13.85 \pm 1.06$ & $111 \pm 1.53$ & $7.5 \pm 0.07$ \\
\hline
\end{tabular}

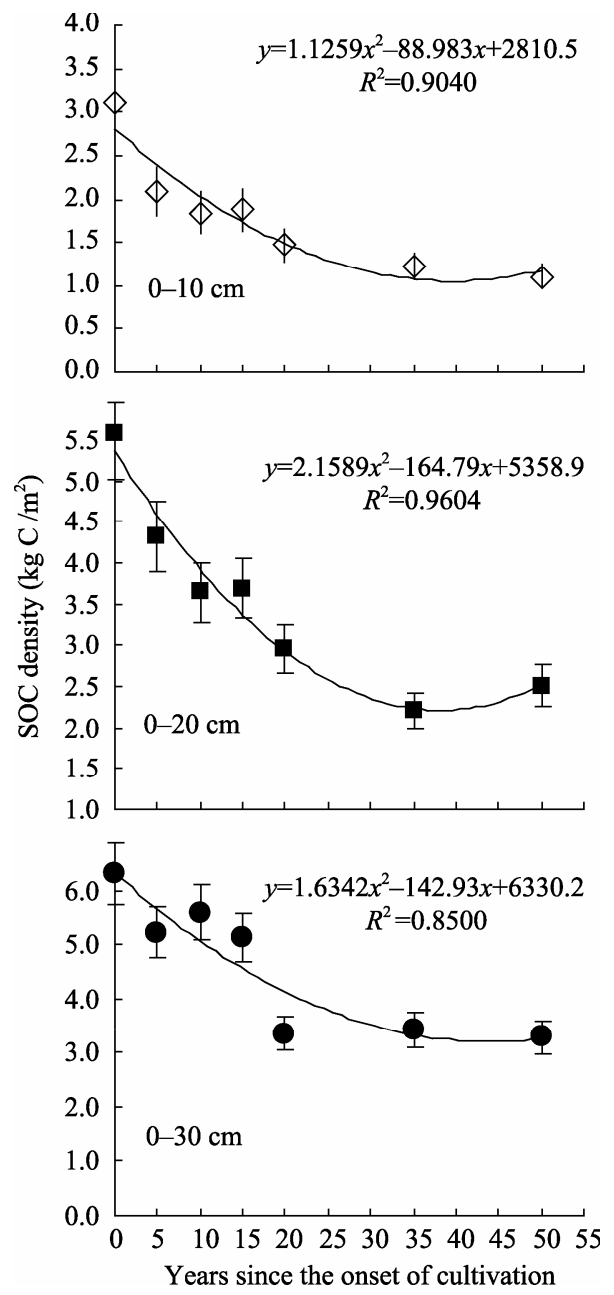

Fig. 1 Correlation of SOC density and cropland reclamation age
Recent experiments in this area suggested that SOC stocks declined after land use changed from grassland to cropland for 10 years, 15 years, and 20 years in the $0-30 \mathrm{~cm}$ soil layers (Jiao et al., 2009). There is generally more SOC under grassland than under cropland (Cole et al., 1993) due to several factors, including the return of more plant residues, higher root biomass, the lack of mechanical disturbance, and erosion in grassland soil. For the cropland soils, the significant SOC losses were partly attributed to cultivation. Balesdent et al. (1998) reported that cultivation could also have contributed to the decrease of physical protection. The physical protection of soil organic matter (SOM) within stable aggregates may be reduced by soil tillage. Bouman (1990), Post and Mann (1990), and Lal et al. (1995) tested that agricultural management practices increased aeration and the loss of carbon to the atmosphere.

Our study proved that the conversion of grassland to cropland induced a significant loss of SOC in the ecotone between agriculture and grazing in Inner Mongolia.

A decrease of SOC density with increased cropland age was found as the age increased from 5 to 50 years. SOC loss was significantly correlated with the time of cropland reclamation in the study area, showing a marked decline in the inceptive years of cultivation. Afterward, the equilibrium in the new land could only 
be reached after 50 years. This result is consistent with Guo's report (Guo et al., 2002).

Land use change $(F=121.4, P<0.0001)$ and cropland age $(F=194.0, P<0.0001)$ distinctly affected soil $\mathrm{TN}$ content. The pattern of nitrogen storage with land use was similar to that of carbon storage. For the 0-30 $\mathrm{cm}$ layers, the lowest TN density $\left(35 \mathrm{~g} \mathrm{~N} / \mathrm{m}^{2}\right.$ for C50 soil) was found in the cropland. The grassland had the highest TN density (65 g N/m ${ }^{2}$ ). Compared with the grasslands, in the $0-30 \mathrm{~cm}$ soil layers, the $\mathrm{C} 5, \mathrm{C} 10$, $\mathrm{C} 15, \mathrm{C} 20, \mathrm{C} 35$, and $\mathrm{C} 50$ soils had a loss of 5\%, 16\%, $23 \%, 38 \%, 44 \%$, and $44 \%$, respectively (Fig. 2).

We applied a regression analysis and found that cropland reclamation age could explain more than $93 \%$,

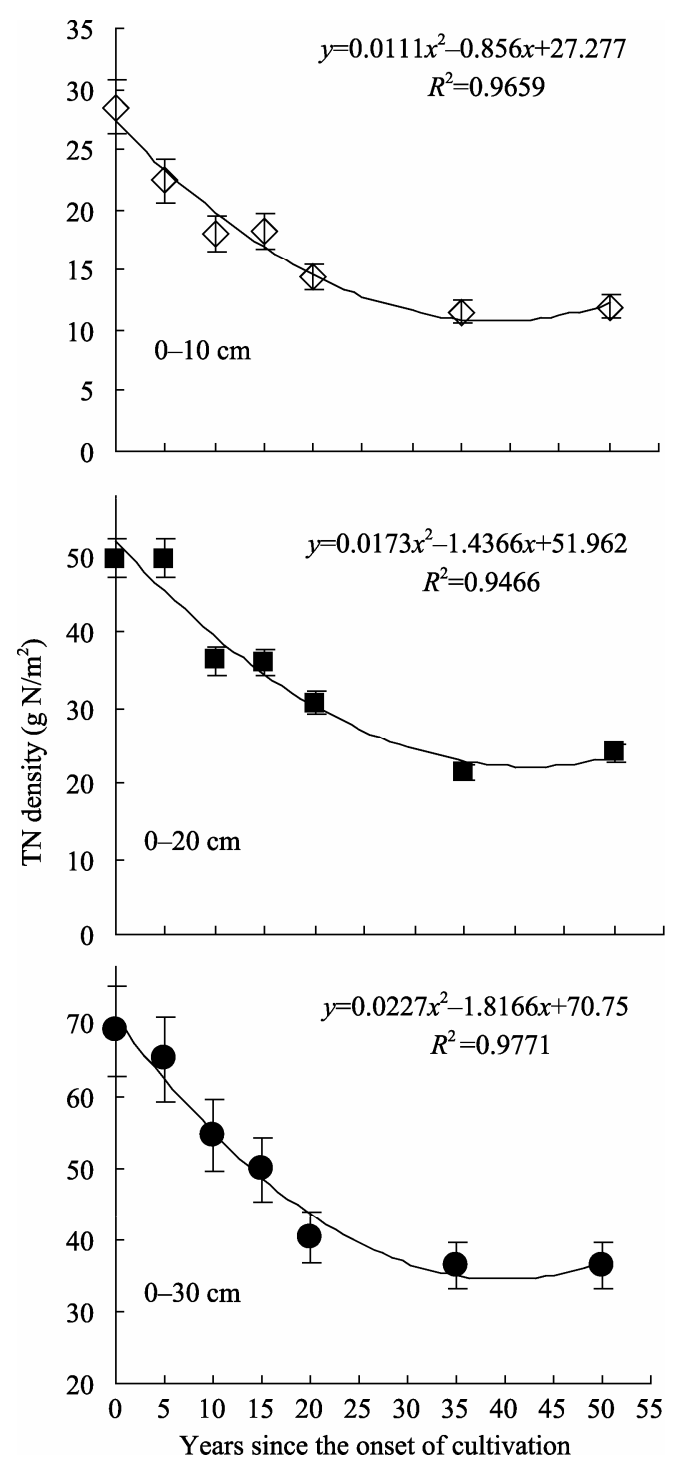

Fig. 2 Correlation of soil TN density and cropland reclamation age
$90 \%$, and $85 \%$ of the variability of SOC density in the 0-10 cm, 0-20 cm, and 0-30 cm soil depths, respectively (Fig. 1). The cropland age also explained more than $95 \%, 91 \%$, and $96 \%$ of the variability of soil $\mathrm{TN}$ density in the $0-10 \mathrm{~cm}, 0-20 \mathrm{~cm}$, and $0-30 \mathrm{~cm}$ soil depths, respectively (Fig. 2).

\subsection{Changes in soil dissolved organic carbon}

Figure 3 shows that land use type $(F=65.3, P<0.0001)$ and cropland age $(F=4.6, P<0.001)$ have pronounced effects on the soil DOC content. The DOC contents decreased in the order of grassland soils, cropland soils in the $0-10 \mathrm{~cm}, 10-20 \mathrm{~cm}, 20-30 \mathrm{~cm}$, respectively. The DOC content of grassland was in the range of 9.1 to $17.8 \mathrm{mg} / \mathrm{L}$ in the 3 soil depths. The DOC value of C50 was 6.5 to $8.9 \mathrm{mg} / \mathrm{L}$ in the 3 soil depths. With increased soil depths, the soil DOC content of the cropland significantly decreased $(F=15.633$, $P<0.0001)$, while that of the grassland soil increased $(F=52.7, P<0.0001)$. Zsolnay (1996) reported that
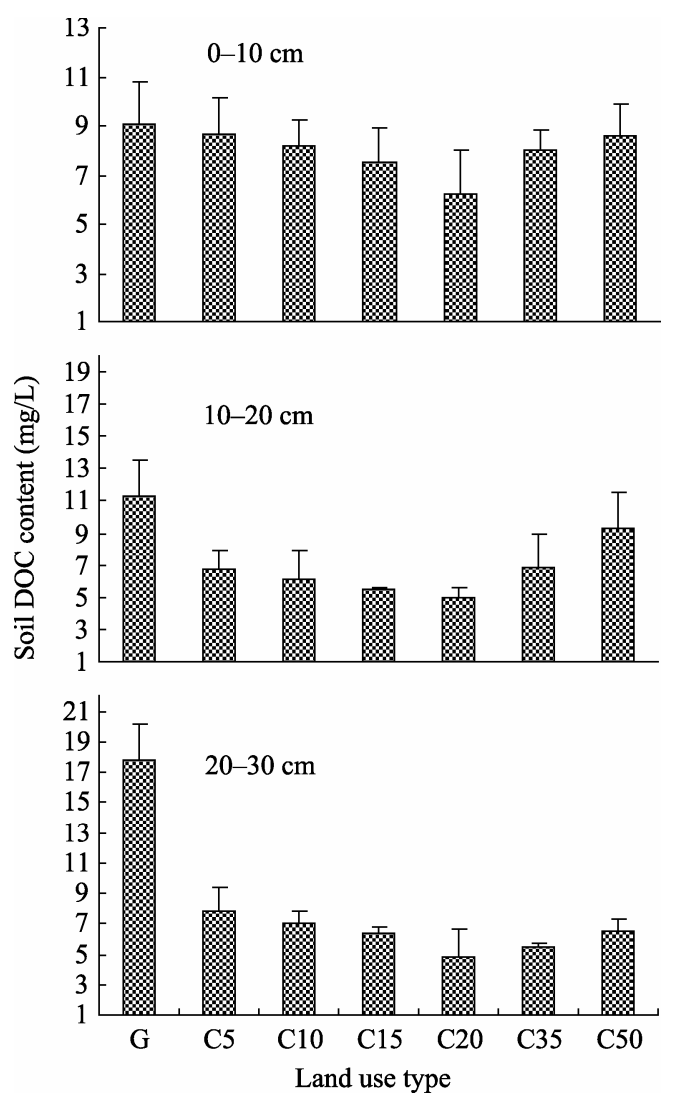

Fig. 3 Comparison of soil dissolved organic carbon (DOC) concentrations and the vertical distributions of croplands of different ages 
agricultural soil DOC values varied from 10 to 70 $\mathrm{mg} / \mathrm{L}$. Other studies have also indicated higher DOC contents in grasslands than in cropland soils (Saviozzi et al., 1994; Gregorich et al., 2000; Haynes, 2000). Moreover, the extent of the decline in DOC appears to be more pronounced in the first 10 years after cropland reclamation. Gregorich et al. (2000) and Haynes (2000) found that DOC content obviously declined as cropland age increased. DOC production and content should be determined primarily by the amount of organic matter in the soil (Zsolnay, 1996; Kalbitz et al., 2000). The factors that controlled the DOC content in the soil were complex because of their diversity, intensity, and heterogeneity in and between treatments. However, our results readily suggest that the difference is generated by land use and cropland age.

In the first 20 years after grassland was converted to cropland, the DOC content showed a decrease with increasing age of cropland at the same soil depths, the contrary is the case in the last 30 years. A possible explanation for this might be that older croplands were more influenced by agricultural practices.

\subsection{Changes in soil AK, AP and pH}

The characteristics of $\mathrm{AP}, \mathrm{AK}$, and $\mathrm{pH}$ at the seven sites as revealed by ANOVA analysis (Table 5) indicated that land use significantly affected AK content $(F=35.5, P<0.0001)$ and $\mathrm{pH}(F=37.5, P<0.0001)$, but did not obviously affect AP content $(F=2.2, P>0.1)$. There were pronounced differences in the AP content
( $F=15.3, P<0.0001)$, AK content $(F=30.8, P<0.0001)$, and $\mathrm{pH}(F=17.4, P<0.0001)$ among cropland soils of different ages. The soil AK content of the grassland soil (between 148 to $282 \mathrm{mg} / \mathrm{kg}$ ) was obviously higher than that of the cropland soil in the $0-30 \mathrm{~cm}$ soil depths. The soil AK content decreased after grassland conversion to cropland in the first 20 years, with a lesser increase in the last 30 years. There were no distinct correlations between $\mathrm{AK}$ content and cropland age $\left(R^{2}=0.3595, P>0.05\right)$.

The AK $(F=6.1, P<0.01)$ and AP $(F=3.9, P<0.0001)$ contents of the grassland and cropland soils obviously decreased $(P<0.01)$ as soil depth increased.

The soil AK loss after the conversion of grassland to cropland could be attributed to soil texture change. A Pearson coefficient correlation analysis shows that soil AK content is mainly negatively correlated with soil BD (Table 6). Kosmas et al. (1993) showed that the mineral composition and textural class of soil significantly affected other soil properties and plant growth. However, soil AP had no difference between the cropland and grassland soils. This result may be due to the fact that soil AP content had no significant correlation with other soil properties (Table 6), which needs to be further studied. Furthermore, there were significant differences in the AP contents among croplands of different ages. One possible explanation is that this discrepancy was the result of different cropland ages. A significant correlation exists between AP content and cropland age $\left(y=0.015 x^{2}-0.3433 x+8.0558\right.$, $R^{2}=0.8626, P<0.01$ ), which means that higher cropland age indicated higher AP content.

Table 6 Matrix of Pearson's correlation coefficients for soil properties

\begin{tabular}{|c|c|c|c|c|c|c|c|c|}
\hline & Cropland Age & TOC & $\mathrm{TN}$ & DOC & $\mathrm{AK}$ & $\mathrm{AP}$ & $\mathrm{pH}$ & $\mathrm{BD}$ \\
\hline TOC & $-0.840^{* *}$ & & & & & & & \\
\hline $\mathrm{TN}$ & $-0.858^{* *}$ & $0.968^{* * *}$ & & & & & & \\
\hline DOC & -0.062 & 0.194 & 0.225 & & & & & \\
\hline $\mathrm{AK}$ & -0.432 & $0.712^{* *}$ & $0.767^{*}$ & 0.336 & & & & \\
\hline $\mathrm{AP}$ & $0.663^{* *}$ & -0.417 & -0.382 & 0.255 & 0.039 & & & \\
\hline $\mathrm{pH}$ & -0.572 & $0.580^{*}$ & $0.653^{*}$ & $0.581^{*}$ & 0.417 & -0.269 & & \\
\hline $\mathrm{BD}$ & 0.356 & $-0.542^{*}$ & $-0.593^{*}$ & -0.267 & $-0.563^{*}$ & -0.039 & $-0.602^{*}$ & \\
\hline Sand & $0.603^{*}$ & $-0.721^{* *}$ & $-0.837^{* *}$ & -0.245 & $-0.722^{* *}$ & 0.073 & $-0.673^{* *}$ & $0.730^{* *}$ \\
\hline Clay & 0.510 & 0.410 & 0.503 & 0.313 & 0.230 & -0.373 & $0.637^{*}$ & -0.323 \\
\hline
\end{tabular}


Our results show that the grasslands had higher nutrient contents (except AP) than croplands, mainly because grasslands have higher clay content and lower bulk density, which is favorable for retaining nutrients.

Table 5 shows that the $\mathrm{pH}$ of the grassland soil was between 8.0 and 8.7 in the $0-30 \mathrm{~cm}$ soil depths. The differences between $\mathrm{pH}$ values are small among the $0-30 \mathrm{~cm}$ soil depths $(F=2.4, P>0.107)$. A trend of decreasing $\mathrm{pH}$ values with increasing ages of cropland was detected, which was likely because the cropland soil tended to become acidic with the advance of reclamation time. However, the $\mathrm{pH}$ was not determined as a function of cropland age $\left(R^{2}=0.5507, P>0.05\right)$. The long-term influence of land use change on $\mathrm{pH}$ was different in the study of Bronson et al. (2004), who compared intensive agricultural sites with grassland sites in the Southern High Plains, USA. The result showed that different types of cotton soils did not have a significantly different $\mathrm{pH}$ value compared with two types of native grassland soil. Strebel et al. (1988) demonstrated that reclaiming grassland and converting it to cropland did not affect soil $\mathrm{pH}$.

\section{Conclusions}

The conversion of grassland to cropland led to soil degradation in the agro-pastoral ecotone of Inner Mongolia. We found that the conversion of grasslands to croplands induced a loss of soil $\mathrm{C}$ and $\mathrm{N}$ in the $0-30$

\section{References}

Angers D A, Caren J. 1998. Plant induced changes in soil structure: process and feedbacks. Biogeochemistry, 42: 55-72.

Balesdent J, Besnard E, Arrouays D, et al. 1998. The dynamics of carbon in particle-size fractions of soil in a forest-cultivation sequence. Plant and Soil, 201: 49-57.

Bauer A, Black A L. 1981. Soil carbon, nitrogen, and bulk density comparisons in two cropland tillage systems after 25 years and in virgin grassland. Soil Science Society of America Journal, 45: $1166-1170$

Bouman A F. 1990. Exchange of greenhouse gases between terrestrial ecosystems and the atmosphere. In: Bouman A F. Soils and the Greenhouse Effect. Chichester: John Wiley Publishers, $61-127$.

Bronson K F, Zobeck T M, Chua T T, et al. 2004. Carbon and nitrogen pools of Southern High Plains cropland and grassland soils. Soil Science Society of America Journal, 68: 1695-1704. $\mathrm{cm}$ soil depths. The conversion of grassland into cropland during the 50-year period decreased soil organic carbon density by $48 \%$ and total nitrogen density by $45 \%$. Moreover, the soil organic carbon density and total nitrogen density revealed a positive correlation with cropland age.

The soil dissolved carbon content, available potassium content, clay content, and $\mathrm{pH}$ value were higher in the grassland than in the cropland soil. The soil available phosphorous content showed no differences between cropland soil and grassland soil. Our study demonstrates that grassland had a higher nutrient content (excluding available phosphorous content) than cropland. A longer cropland age was correlated with a lower soil nutrient content. A trend of higher soil sand content and lower clay content was observed with increasing cropland age.

How to improve soil quality will be a future concern in the study area. Based on our results, we conclude that frequent cultivation should be strictly avoided, and conservation tillage is expected to significantly prevent soil organic carbon loss and enhance soil organic carbon sequestration in the croplands.

\section{Acknowledgements}

This work was funded by the National Natural Science Foundation of China (41165010), the State Key Basic Research and Development Plan of China (2007CB106806), and the State Key Laboratory Fund of Institute of Atmospheric Physics, Chinese Academy of Sciences (LAPC-KF-2008-03).

Cambardella C A, Elliot E T. 1992. Particulate soil organic-matter changes across a grassland cultivation sequence. Soil Science Society of America Journal, 56: 777-783.

Celik I. 2005. Land-use effects on organic matter and physical properties of soil in a southern Mediterranean highland of Turkey. Soil and Tillage Research, 83: 270-277.

Chen Z Z, Wang S P. 2000. Typical Steppe Ecosystem in China. Beijing: Science Press.

Cole C V, Flach K, Lee J, et al. 1993. Agricultural sources and sinks of carbon. Water, Air, \& Soil, 70: 111-122.

de Castro A J, Meneses J, Brize S, et al. 1999. Nondispersive infrared monitoring of $\mathrm{NO}$ emissions in exhaust gases of vehicles. Review of Scientific Instrument, 70: 3156-3159.

Delprat L, Chassin P, Lineres M, et al. 1997. Characterization of dissolved organic carbon in cleared forest soils converted to maize cultivation. European Journal of Agronomy, 7: 201-210. 
Elliott E T. 1986. Aggregate structure and carbon, nitrogen, and phosphorus in native and cultivated soils. Soil Science Society of America Journal, 50: 627-633.

Evrendilek F, Celik I, Kilic S. 2004. Changes in soil organic carbon and other physical soil properties along adjacent Mediterranean forest, grassland, and cropland ecosystems in Turkey. Journal of Arid Environments, 59: 743-752.

Franzluebbers A J, Stuedemann J A, Schomberg H H, et al. 2000. Soil organic $\mathrm{C}$ and $\mathrm{N}$ pools under long-term pasture management in the Southern Piedmont USA. Soil Biology \& Biochemistry, 32: 469-478.

Gregorich E G, Liang B C, Drury C F, et al. 2000. Elucidation of the source and turn over of water soluble and microbial biomass carbon in agricultural soils. Soil Biology \& Biochemistry, 32: 581-587.

Guo L B, Gifford R M. 2002. Soil carbon stocks and land use change: a meta analysis. Global Change Biology, 8: 345-360.

Hajabbasi M A, Jalalian A, Karimzadeh H R. 1997. Deforestation effects on soil physical and chemical properties, Lordegan, Iran. Plant and Soil, 190: 301-308.

Han X G, Li L H, Huang J H. 1999. An Introduction to Biogeochemistry. Beijing: China Higher Education Press, 197-244.

Haynes R J. 2000. Labile organic matter as an indicator of organic matter quality in arable and pastoral soils in New Zealand. Soil Biology \& Biochemistry, 32: 211-219.

He W Q, Zhao C X, Gao W S. 2005. Main affecting factors of soil wind erosion under different land use patterns - a case study in Wuchuan county, Inner Mongolia. Chinese Journal of Applied Ecology, 16(11): 2092-2096.

Horneck D A, Miller R O. 1998. Determination of total nitrogen in plant tissue. In: Kalra Y P. Handbook and Reference Methods for Plant Analysis. New York: CRC Press, 75-83.

Houghton R A . 1999. The annual net flux of carbon to the atmosphere from changes in land use 1850-1990. Tellus B, 51: 298-313.

Jiao Y, Xu Z, Zhao J H. 2009. Effects of grassland conversion to cropland and forest on soil organic carbon and dissolved organic carbon in the farming-pastoral ecotone of Inner Mongolia. Acta Ecologica Sinica, 29: 150-154.

Kalbitz K, Solinger S, Park J H, et al. 2000. Controls on the dynamics of dissolved organic matter in soils: a review. Soil Science, 165: 277-304.

Kosmas C, Danalatos N, Moustakas N, et al. 1993. The impacts of parent material and landscape position on drought and biomass production of wheat under semi-arid conditions. Soil Technology, 6: 337-349.

Lal R, Kimble J, Stewart B. 1995. World soils as a source or sink for radiatively active gases. In: Lal R, Kimble J, Levine E, et al. Soil Management and Greenhouse Effect. Boca Raton Florida: Lewis Publishers, 1-8.

Lal R. 2002. Soil carbon dynamics in cropland and rangeland. Environmental Pollution, 116: 353-362.
Li Y B, Xie D, Wang S, et al. 2006. Impact of land cover types on the soil characteristics in karst area of Chongqing. Journal of Geographical Sciences, 16(2): 143-154.

Liu G S. 1996. Soil Physical and Chemical Analysis \& Description of Soil Profiles. Beijing: China Standard Press.

Liu J Y. 2002. Analysis on the change of land use and cover spatial pattern in China. Science in China Series D: Earth Sciences, 32(12): 1031-1039.

Liu Q Y, Tong Y P. 2003. The effects of land use on the eco-environmental evolution of farming-pastoral region in North China: with an emphasis on Duolun county in Inner Mongolia. Acta Ecologica Sinica, 23: 1025-1030.

Mapa R B, Kumaragamage D. 1996. Variability of soil properties in a tropical Alfisol used for shifting cultivation. Soil Technology, 9: 187-197.

Martin D, Tarsem L, Sachdev C B, et al. 2010. Soil organic carbon storage changes with climate change, landform and land use conditions in Garhwal hills of the Indian Himalayan Mountains. Agriculture, Ecosystems \& Environment, 138: 64-73.

Mooney H A, Vitousek P V, Matson P A. 1987. Exchange of materials between terrestrial ecosystems and the atmosphere. Science, 238: 926-932.

Pedersen T A, Rogowski A S, Pennock R J. 1980. Physical characteristics of some mine soils. Soil Science Society of America Journal, 44: 321-328.

Post W M, Mann L K. 1990. Change in soil organic matter and nitrogen as a result of cultivation. In: Bouman A F. Soil and the Greenhouse Effect. Chichester: John Wiley Publication.

Post W M, Kwon K C. 2000. Soil carbon sequestration and land-use change: processes and potential. Global Change Biology, 6: 317-327.

Potter C S, Matson P A, Vitousek P M, et al. 1996. Process modeling of controls on nitrogen trace gas emissions from soils worldwide. Journal of Geophysical Research, 101(D1): 1361-1377.

Powlson D S. 2005. Will soil amplify climate change. Nature, 433: 204-205.

Shukla M K, Lal R, Underwood J, et al. 2004a. Physical and hydrological characteristics of reclaimed mine soils in southeastern Ohio. Soil Science Society of America Journal, 68: 1352-1359.

Shukla M K, Lal R, Ebinger M. 2004b. Soil quality indicators for reclaimed minesoils in southeastern Ohio. Soil Science, 169(2): 133-142.

Skousen J, Sencindiver J, Owens K, et al. 1998. Physical properties of minesoils in West Virginia and their influence on wastewater treatment. Journal of Environmental Quality, 27: 633-639.

Strebel O, Böttcher J, Aldag R. 1988. Quantitative and qualitative changes in soil properties of A-horizons of sandy soils caused by conversion of grassland to arable land. Journal of Plant $\mathrm{Nu}$ trition and Soil Science, 151: 341-347.

Taipusi County Record Compilation Committee. 2000. Taipusi 
County Record. Hailaer: Inner Mongolia Cultural Press.

Tisdall J M, Oades J M. 1982. Organic matter and water stable aggregates in soils. Journal of Soil Science, 33: 141-163.

Wang Y S, Wang Y H. 2007. Observation of Carbon Exchange on Typical Terrestrial Ecosystems and Freshwater. Beijing: Science Press, 158-159.

Wu H B, Gu Z T, Pen C H. 2003. Land use induced changes of organic carbon storage in soils of China. Global Change Biology, 9: 305-315.

Wu R, Tiessen H. 2002. Effect of land use on soil degradation in Alpine grassland soil, China. Soil Science Society of American Journal, 66: 1648-1655.

Yang X C, Yan P, Liu L Y, et al. 2005. Wind tunnel experiment on effects of different cultivation patterns on soil wind erosion in agro-grazing ecotone in Inner Mongolia. Acta Pedologica Sinica, 42(5): 738-743.

Zhan J Y, Deng X Z, Yue T X. 2004. Land use change and its environmental effects in the farming-pasturing interlocked areas of Inner Mongolia. Resources Science, 26(5): 80-88.

Zhang X S, Gao Q, Yang D A, et al. 1997. A gradient analysis and prediction on the Northeast China Transect (NECT) for global change study. Acta Botanica Sinica, 39: 785-799.

Zhang G L. 2010. Changes of soil labile organic carbon in different land uses in Sanjiang Plain, Heilongjiang Province. Chinese Geographical Science, 20(2): 139-143.

Zhou Z Y, Osbert J, Huang J H, et al. 2007. Soil carbon and nitrogen stores and storage potentials affected by land-use in an agro-pastoral ecotone of northern China. Biogeochemistry, 82: 127-138.

Zou Y R. 2003. Analysis on driving forces of typical zones land use change in ecotone between agriculture and animal husbandry and its impacts on soil erosion. Ph.D. Dissertation, Beijing: Graduate University of Chinese Academy of Sciences.

Zsolnay A. 1996. Dissolved humus in soil waters. In: Piccolo A. Humic Substances in Terrestrial Ecosystems. Amsterdam: Elsevier, 171. 